mediastudies.press • Social Media \& the Self: An Open Reader

\title{
When Your Authenticity Is an Act, Something's Gone Wrong
}

Joseph E. Davis

Published on: Mar 31, 2021

DOI: $10.32376 / 3 f 8575 c b .774 a 7 e 8 b$

License: Creative Commons Attribution-NonCommercial 4.0 International License (CC-BYNC 4.0). 
'TODAY THERE IS little premium placed on being authentic,' writes the American philosopher Gordon Marino in his moving meditation The Existentialist's Survival Guide: How to Live Authentically in an Inauthentic Age (2018). In our world of 'selfies, social media branding, and managing your profile on LinkedIn and Facebook ... [i]t is not who you are but who you seem to be!' In interviews for my own sociological book on everyday suffering and our troubled quest for self-mastery, I too found little premium placed on 'being authentic'. And yet, organisational consultants inform us, in the pages of the Harvard Business Review, that 'the term "authenticity" has become a buzzword among organisational leaders'. In fact, authenticity is 'now ubiquitous in business, on personal blogs and even in style magazines', according to another writer. 'Everyone wants to be authentic.'

So, which is it? Is authenticity fading away as a personal ethic or is it something everyone wants to be? In fact, both are true-because the meaning of authenticity is changing....

continue reading

\section{OUTBOUND LINK}

"When Your Authenticity Is an Act, Something's Gone Wrong." (Joseph E. Davis, Psyche, March 31, 2021)

FREE ACCESS 